\title{
WRITTEN IN THE SKIES: ADVERTISING, TECHNOLOGY, AND MODERNITY IN BRITAIN SINCE 1885
}

\author{
James Taylor, Lancaster University, UK
}

This is an Author Accepted Manuscript version of an article that will be published in the Journal of British Studies. http://journals.cambridge.org/action/displayJournal?jid=JBR

It is a strange thing how little in general people know about the sky ... Sometimes gentle, sometimes capricious, sometimes awful, never the same for two moments together; almost human in its passions, almost spiritual in its tenderness, almost divine in its infinity ... yet we never attend to it, we never make it a subject of thought. ${ }^{1}$

Scholars in a variety of disciplines have studied how past societies experienced and gave meaning to the landscapes they inhabited. Theologian Belden C. Lane has explored how some spaces come to be recognized as sacred as a result of "the stories that are told about them," and stresses the role of the imagination in constructing place. ${ }^{2}$ Archaeologist Christopher Tilley applies a phenomenological approach to landscape research in order to understand "how people in the past made sense of, lived in, and understood their landscapes," arguing that social life is always rooted within landscape rather than taking place "somehow

\footnotetext{
${ }^{1}$ John Ruskin, “Modern Painters” (1843), reprinted in John Ruskin, Selections and Essays (New York, 1918), $30-1$.

${ }^{2}$ Belden C. Lane, Landscapes of the Sacred: Geography and Narrative in American Spirituality (Baltimore, $2002[1988]), 15,241$.
} 
on top of it or outside it."3 Historian Jeremy Burchardt has shown how the British countryside came to be reinvented "as an object of consumption" rather than a site of work, becoming "a place to retreat to (often in the imagination) from an unacceptable or unbearable contemporary world," and eventually being elevated into "the wellspring of national identity and refuge from the modern urban world."4

Though methodologically diverse, one thing these works have in common is that, by and large, their focus lies below the horizon: they write about landscapes not skyscapes. This might seem natural enough: indeed, we could draw a distinction between landscape as "place" and the sky as simply "empty space." Yet, as Fabio Silva has recently noted, the sky is also "a natural phenomenon that is turned into a cultural skyscape through human agency." ${ }^{, 5}$ Borrowing a metaphor first coined by Tilley, Nicholas Campion argues that the sky, just as much as the landscape, "can be seen as a palimpsest containing sedimented layers of meaning, a cultural record of the past, an archaeological source if we care to use it." Moreover, "landscapes do not exist without skyscapes," so that any study of landscape which ignores skyscapes can only give a partial picture. ${ }^{6}$

When we think of the cultural significance of the sky in past ages, our first thought is probably of divine portents. The idea that the Gods used the sky to warn and chastise humanity can be traced back to Ancient Mesopotamia, through Greece and Rome, to the Old

\footnotetext{
${ }^{3}$ Christopher Tilley, Interpreting Landscapes: Geologies, Topographies, Identities (Walnut Creek, 2010 ), 31. See also Christopher Tilley, A Phenomenology of Landscape: Places, Paths, and Monuments (Oxford, 1994). ${ }^{4}$ Jeremy Burchardt, Paradise Lost: Rural Idyll and Social Change since 1800 (London, 2002), 9-11. ${ }^{5}$ Fabio Silva, "The Role and Importance of the Sky in Archaeology: An Introduction," in Skyscapes: The Role and Importance of the Sky in Archaeology, ed. Fabio Silva and Nicholas Campion (Oxford, 2015), 1-7, at 2. ${ }^{6}$ Nicholas Campion, “Skyscapes: Locating Archaeoastronomy within Academia,” in Silva and Campion, eds., Skyscapes, 8-19, at 8-9.
} 
and New Testaments, lingering long into early-modern societies. ${ }^{7}$ For centuries, therefore, the sky was a source of fascination, inspiration, and, above all, fear. The modern age is typically thought of as a rupture with this way of looking at the sky. The rise of science is believed to have triggered a "transition from a religious to a secular conception of the 'heavens,", as a result of which the sky lost its traditional significance. ${ }^{8}$ Others see developments within religious as key, namely Protestantism's cutting of "the umbilical cord between heaven and earth." As Peter Berger argues, "A sky empty of angels becomes open to the intervention of the astronomer and, eventually, of the astronaut." ${ }^{\text {9 }}$ But just as recent work on religion in modern Britain posits secularization as a more complex and far slower process than once believed, ${ }^{10}$ so we need to revisit the assumption that modern skies have been drained of their meaning.

This article approaches the subject by examining the development and regulation of various forms of sky advertising made possible by commercial and technological advances in Britain from the 1880s. It is sometimes assumed that technological innovation left advertising largely untouched until the radio and television age: in the Victorian era it had to content itself with "defacing train station after train station." ${ }^{11}$ In fact, technology opened up the

\footnotetext{
${ }^{7}$ Divination and Interpretation of Signs in the Ancient World, ed. Amar Annus (Chicago, 2010); David H. Levy, The Sky in Early Modern English Literature: A Study of Allusions to Celestial Events in Elizabethan and Jacobean Writing, 1572-1620 (Springer, 2011); Alexandra Walsham, "Sermons in the Sky: Apparitions in Early-Modern Europe," History Today 51, no. 4 (April 2001), 56-63, at 57-8.

${ }^{8}$ Kevin Robins and Frank Webster, Times of the Technoculture: From the Information Society to the Virtual Life (London, 1999), 29-30.

${ }^{9}$ Peter Berger, The Sacred Canopy: Elements of a Social Theory of Religion (New York, 1990 [1967]), 113.

${ }^{10}$ Callum Brown, The Death of Christian Britain: Understanding Secularisation, 1800-2000 (London, 2000).

${ }^{11}$ Thomas Richards, The Commodity Culture of Victorian England: Advertising and Spectacle, 1851-1914 (London, 1991), 254-5.
} 
heavens to adventurous advertisers, but this history has been largely ignored by scholars, save for a short chapter in E. S. Turner's popular history of advertising, published over half a century ago. ${ }^{12}$ Turner sees the topic as an amusing but ultimately trivial subplot in the wider development of advertising. This article takes a different line, arguing that debates on sky advertising provide illuminating new perspectives on how the British experienced technology, modernity, and commercial culture.

Sky advertising often provoked horrified responses, and it is tempting to see these as evidence to support Martin Wiener's thesis that English culture never fully came to terms with commerce or technology, contributing to the nation's economic decline. ${ }^{13}$ But other assessments are possible. In recent years, "declinist" interpretations have given way to a greater interest in the British experience of modernity. Bernhard Rieger and Martin Daunton argue that rather than outright rejection (or enthusiastic embrace), British responses to modernity were characterized by ambivalence, and often involved adopting some aspects of the modern and condemning others. ${ }^{14}$ This article resists depicting opponents of aerial advertising as over-sensitive aesthetes or technophobes. The controversy does not signify a nation at odds with modernity, for not all forms of advertising were condemned, and not all incursions into the sky were loathed. But the combination of the two sparked visceral opposition. This opposition suggests that far from turning the sky into empty space, urbanization and commercial development had in fact imbued the sky with new significance.

\footnotetext{
${ }^{12}$ E. S. Turner, The Shocking History of Advertising (Harmondsworth, 1965 [1952]), 256-65. Early experiments in projecting messages into the night sky are briefly discussed in Carolyn Marvin, When Old Technologies Were New: Thinking About Electric Communication in the Late Nineteenth Century (Oxford, 1988), 184-9.

${ }^{13}$ Martin J. Wiener, English Culture and the Decline of the Industrial Spirit, 1850-1980 (Cambridge, 1981).

${ }^{14}$ Bernhard Rieger and Martin Daunton, "Introduction," in Meanings of Modernity: Britain from the LateVictorian Era to World War II, ed. Martin Daunton and Bernhard Rieger (Oxford, 2001), 1-21, at 7-8.
} 
The article begins by briefly sketching the various forms taken by aerial advertising, while the second section summarizes legislative interventions to restrict or prohibit them. The following sections seek to explain why sky advertising generated such determined opposition over such a long period of time, and what this hundred-year history of resistance tells us about a society negotiating its relationship with technology and commercial culture.

\section{VARIETIES OF SKY ADVERTISING}

Advertising's first foray into the skies came in September 1885, when Augustus Harris, manager of Drury Lane's Theatre Royal, began advertising his establishment by means of a captive balloon fixed to the roof, on which was painted the name of the theatre. ${ }^{15}$ His supplier was the balloon manufacturers Charles Green Spencer and Sons, and by the following May the firm had sold at least a dozen, with theatrical companies the main customer. ${ }^{16}$ The balloons, which had a circumference of forty-six feet, and bore black letters of four-to-five feet, could be "seen flying over London every day", and soon spread to other cities. ${ }^{17}$ The balloons took lots of different forms - "horses, cows, elephants, and human figures" - while others were lit by electricity, to create a "Globe of Fire" effect, which meant that they could be seen at night. ${ }^{18}$

Balloons were soon followed by "sky signs:” large letters made out of wood or metal fixed onto a galvanized iron framework and set onto the roof of business premises, as these

\footnotetext{
${ }^{15}$ County Gentleman, 26 September 1885, 1223.

${ }^{16}$ Pall Mall Gazette, 10 May 1886, 4-5.

${ }^{17}$ Manchester Times, 17 October 1885, 7; The Era, 1 May 1886, 8; Isle of Man Times and General Advertiser, 4 September 1886, 5;

${ }^{18}$ Western Mail, 8 May 1886, 2; The Era, 28 November 1885, 3.
} 
examples from Piccadilly Circus show (figure 1). The letters, each about six to eight feet high and four feet wide, were free to swing in the breeze, to minimize wind resistance, and could be set up to eighty feet above the roof for maximum visibility. ${ }^{19}$ At night, when lit artificially or by moonlight, the letters could be read, but the framework was invisible, creating the "weird, uncanny effect" of the advert appearing "to be written in the sky." 20 By the middle of 1890 the inventor, enterprising shop-fitter Frederick Sage, had sold about sixty sky signs to firms in London and the major cities, including Eno's Salts, Mazawattee Tea, and the Royal Liver Friendly Society. ${ }^{21}$ The later 1890 s saw the arrival of electric or gas-lit signs erected on buildings, which were also sometimes known as "sky signs" though they were usually affixed to the sides of buildings. These were concentrated in the focal points of London night-life: first Trafalgar Square, and later Piccadilly Circus. ${ }^{22}$

The new century heralded technologies which brought the sky more within the reach of man - and of advertisers. The first was the airship. Alberto Santos-Dumont's successful flight around the Eiffel Tower in 1901 sparked a worldwide airship craze; in Britain the Spencer family, who had developed the captive advertising balloon, led the way, but in the absence of government funding, desperately needed private sponsorship. Stanley Spencer, one of Charles Green Spencer's six aviator sons, struck a deal with Mellin's Food, a baby food manufacturer: in return for $£ 1,500$, the company’s name was painted in ten-foot letters on the sides of the balloon, and it carried promotional literature as ballast. ${ }^{23}$ The press reported extensively on what became known as the "Mellin Airship" through the summer of

\footnotetext{
${ }^{19}$ Pall Mall Gazette, 29 August 1890, 6.

${ }^{20}$ Western Mail, 4 September 1890, 4.

${ }^{21}$ The Standard, 18 June 1890, 4. For Sage's obituary, see North-Eastern Daily Gazette, 7 October 1898, 4.

${ }^{22}$ The Times, 31 January 1899, 7.

${ }^{23}$ Spencer Brothers v. Mellin's Food (Limited) (1903), The Times, 29 October 1903, 13.
} 
1902 as it underwent public tests, and in September Spencer made his maiden voyage across London. ${ }^{24}$ Other sponsors followed - the Spencers' 1903 airship was paid for by the Evening News, in 1908 they did a deal with London department store Gamage's, while in 1913 their airship proclaimed "Give him Bovril."25

It was the airplane, however, that promised to launch advertising into the skies in a major way. The rapid advance of the technology, from the Wright Brothers' first powered flight in 1903 to the development of fighter aircraft during the Great War, attracted the attention of the business-minded, while the ready availability of cheap aircraft and trained pilots after the war increased commercial viability. ${ }^{26}$ But what form would the new advertising take? Predictions that firms would buy aircraft and decorate them "just as certain firms now decorate their delivery vans," and that planes would drop so many advertising pamphlets that they would "choke the gutter and disfigure streets in many towns," proved wide of the mark. ${ }^{27}$ The answer came on Derby Day 1922, when racegoers were treated to a novel sight: an airplane writing the words "Daily Mail" in smoke trails across the sky. The stunt was repeated twice the following day in the skies over London, in the morning over Hyde Park and in the evening over St Paul's: the next day's Mail carried an artist's idealized depiction of the display. The paper boasted that this was "the largest advertisement the world has ever known" - the two words measured three miles across, and were seen by millions. ${ }^{28}$

\footnotetext{
${ }^{24}$ The Times, 24 June 1902, 10; 7 July 1902, 9; 22 September 1902, 8.

${ }^{25}$ Ibid., 10 December 1908, 13; http://www.earlyaeroplanes.com/archive3.htm.

${ }^{26}$ Peter Fearon, "The Growth of Aviation in Britain," Journal of Contemporary History 20, no. 1 (January 1985): $21-40$ at 24.

${ }^{27}$ Paul Bewsher in Daily Mail, 14 January 1919, 4.

${ }^{28}$ Daily Mail, 1 June 1922, 8; 2 June 1922, 7-8.
} 
The inventor of this new advertising technique, which quickly became known as “skywriting," was Major Jack Savage, one of Britain's first pilots and former manager of a flying circus, who had served with the Royal Naval Air Service during the war. The flights, some of which also advertised Castrol for C. C. Wakefield and Co., Zam-Buk ointment, and the Combined Hospitals Appeal, soon began targeting northern cities along with coastal resorts. ${ }^{29}$ By May 1924, skywriting was reaching up to twenty towns a day, and Savage had seventeen pilots working not only in Britain but also the US, Canada, France, and Sweden. ${ }^{30}$ Skywriting became a regular feature of Hendon air pageants and other air shows. ${ }^{31}$

Savage was also the inventor of a method of putting advertising into the night sky. Experiments had long been made in projecting words and images, usually by means of a stencil placed over a searchlight, but with limited success. ${ }^{32}$ Savage developed an alternative method, which involved using mirrors to break up the light, equivalent to that produced by three billion candles, into 300 separate rays, and deflecting each ray along different paths in order to spell words. Working in conjunction with Dublin brewers Guinness, Savage experimented with his projector at his Hendon base and also in locations across the South of England through 1930-1, placing advertisements in the press asking local people to provide

\footnotetext{
${ }^{29}$ Ibid., 19 August 1922, 3; Manchester Guardian, 2 July 1922, 9.

${ }^{30}$ Daily Mail, 11 August 1924, 8; 30 May 1924, 7. Skywriting had reached Paris in October and New York in November 1922: Daily Mail, 13 October 1922, 7; 29 November 1922, 9.

${ }^{31}$ The Times, 23 August 1926, 7; 4 June 1927, 7.

32 Another British inventor, Harry Grindell Matthews, who claimed in the 1920s to have invented a "death ray," developed a sky projector using stencils, and demonstrated it in New York and in London, but it does not seem to have been a success, despite excited press coverage: Popular Science Monthly, February 1928, 22; The
} Scotsman, 24 December 1930, 10. 
feedback on visibility. ${ }^{33}$ The new technology, which was also popularly known as skywriting, inspired imitators. July 1932 saw a demonstration of skywriting by one of Savage's rivals from the roof of the Ritz Hotel, while in October it was announced that a "Night Sky Telegram” would project news over central London, interspersed with advertising messages. ${ }^{34}$ The following January, crowds in Blackheath were dazzled by a series of sky projections including a second moon projected next to the real one, causing the Daily Express to announce "the coming of the era of "sky signs.", 35

However, the most common form of sky advertising in the 1930s was a more basic technology. Advertising banners towed by aircraft first appeared in $1930,{ }^{36}$ and though initially overshadowed by Savage's skywriting, their relatively low cost and novelty value meant that they grew in popularity with advertisers, one firm boasting that its "sky posters" caught the eyes of millions. ${ }^{37}$ Advertising agencies like J. Walter Thompson recommended the medium for new brands trying to compete against well-established rivals on the grounds that such "stunt" publicity attracted lots of attention. ${ }^{38}$ Indeed, in 1937, Advertising World noted that advertising banners were "gaped-at by everyone for miles around" regardless of the goods being advertised. ${ }^{39}$

\footnotetext{
${ }^{33}$ See for example Surrey Mirror and County Post, 30 January 1931, 8; Portsmouth Evening News, 7 March $1931,5$.

${ }^{34}$ The Times, 15 July 1932, 9; 12 October 1932, 10.

35 Daily Express, 11 January 1933, 9.

${ }^{36}$ The Times, 4 July 1930, 21.

${ }^{37}$ Air Publicity Ltd, Advertising World 69, no. 2 (February 1937): 59; 69, no. 3 (March 1937): 55; 69, no. 5 (May 1937): 55.

${ }^{38}$ Planning Campaigns and Market Research for Murray's Cigarettes, 1936-43, History of Advertising Trust Archive, HAT 50/1/112/1/11, W. Tisbury to Mr. Rodgers, Murray’s Tobacco, 24 January 1936.

${ }^{39}$ Advertising World 69, no. 2 (February 1937): 49.
} 
All of these methods of sky advertising were homegrown; the final one, however, was an American import. One January afternoon in 1932, "Hundreds of thousands of people all over New York City ... ran to their windows and their roofs at the strange sound of a powerful voice resounding through offices and homes." The heavily amplified voice, appealing for charitable donations to help the unemployed, came from an airship 1000 feet in the sky; it was followed by the sound of a jazz orchestra playing "Happy Days Are Here Again." ${ }^{40}$ Though the episode sparked fears that "sky shouting," as it became known, would soon be heard in Britain, it did not actually arrive until the mid-1950s, when it became an occasional, if not a common, experience, mostly in urban areas. ${ }^{41}$ While there were subsequent developments in sky advertising, such as "flying billboards," these were refinements of earlier techniques rather than entirely new methods. ${ }^{42}$

\section{PURGING THE SKIES}

Though these aerial advertisements could excite wonder and excitement, ${ }^{43}$ they also generated negative responses, ranging from mild unease to near panic, which led to demands for legislative intervention. The advertising balloons of the 1880 s made some Londoners pray for the smog to descend to render them invisible, while others took matters into their own hands, shooting at the balloons under cover of nightfall, forcing owners to deflate and store

\footnotetext{
${ }^{40}$ The Times, 15 January 1932, 12.

${ }^{41}$ Ibid., 12 July 1954, 5; 25 May 1955, 6.

${ }^{42}$ Ibid., 28 November 2003, 45.

${ }^{43}$ For more on the language of "wonder," see Bernhard Rieger, Technology and the Culture of Modernity in Britain and Germany, 1890-1945 (Cambridge, 2005), 20-1.
} 
them overnight. ${ }^{44}$ Sky signs triggered a stronger response. J. M. S. Brooke, a well-known City clergyman, wrote to The Times "In the name of all that is graceful and beautiful" to "protest against the sky signs which now disfigure London," with their "hideous webweaving of the very sky above us. ${ }^{245}$ Brooke's complaint struck a chord, sparking a flurry of correspondence to the paper, mostly critical of the spread of sky signs. ${ }^{46}$ The complaints soon developed into a storm of controversy as leader writers weighed in to the debate. ${ }^{47}$ The strength of opposition inspired the newly formed London County Council (LCC) to secure a local act in 1891 banning the erection of new sky signs and compelling the removal of all signs after six years. ${ }^{48}$ Nearly 250 signs were taken down in the first two years of the act, ${ }^{49}$ but problems enforcing it ${ }^{50}$ led the LCC to seek a more comprehensive definition of a sky sign, achieved in the London Building Act of $1894 .{ }^{51}$ This included balloons and flags used for advertising purposes "on, over, or above any building." ${ }^{52}$ Following the LCC's example,

\footnotetext{
${ }^{44}$ Manchester Times, 17 October 1885, 7; Aberdeen Weekly Journal, 17 September 1890, 5.

45 The Times, 26 August 1890, 3.

46 The letters ran from 27 August to 6 September 1890.

${ }^{47}$ Leeds Mercury, 3 September 1890, 4; Birmingham Daily Post, 3 September 1890, 4; Liverpool Mercury, 8 September 1890, 5 .

${ }^{48}$ The Times, 10 December 1890, 7; Daily News, 10 December 1890, 2; Newcastle Weekly Courant, 31 January 1891, 3; Morning Post, 16 March 1891, 5; Sky Signs Act, 1891, 54 \& 55 Vict. c. 1xxviii.
}

${ }^{49}$ A Beautiful World 3 (June 1894): 89.

${ }^{50}$ London County Council v. Carwardine and Co. (1892), The Times, 2 November 1892, 3; Madame Tussaud and Sons, Appellants - The London County Council, Respondents (1892), The Times, 11 November 1892, 13. ${ }^{51}$ The Times, 1 February 1893, 10; London County Council (General Powers) Act 1893: 56 \& 57 Vict. c. ccxxi; London Building Act, 1894, 57 \& 58 Vict. c. ccxiii, part xii.

${ }^{52}$ London Building Act 1894, s. 125. For examples of the legislation being used against advertising flags, see: The Times, 10 December 1924, 11; 2 May 1925, 4; Illustrated London News, 23 May 1925, 1034. The LCC was less successful in tackling electric signs: Survey of London: St James Westminster, Part 2, xxxi-xxxii, ed. F. H. 
other local authorities began applying to parliament for powers to regulate sky signs, including Edinburgh (1896) and Dover (1901). ${ }^{53}$ In 1903 the Burgh Police (Scotland) Act included a section enabling local authorities to ban sky signs. ${ }^{54}$ An almost identical section featured in the Public Health Acts Amendment Act of 1907 for England and Wales. ${ }^{55}$ By these means, the original LCC ban was extended to the entire country. By September 1910, 154 cities, towns, and districts in England and Wales had used the powers to outlaw sky signs, while several others already did so under their private Acts. ${ }^{56}$

Skywriting also had its critics, one Conservative peer complaining that "We suffer quite enough from the Daily Mail on earth without being plagued by it from heaven." ${ }^{57}$ In 1923, the Society for Checking the Abuses of Public Advertising (SCAPA), a pressure group formed in 1893, added a clause banning skywriting to the bill it was promoting to regulate advertising. The measure passed the Lords only to fail in the Commons; the anti-skywriting clause was removed from the 1924 version of the bill. ${ }^{58}$ But Savage's projector attracted more sustained opposition. SCAPA, changing its tactics, wrote to the Air Ministry in 1931 to point out the danger Savage's invention posed to air navigation given that his projections

W. Sheppard (London, 1963), 85-100, online ed. http://www.british-history.ac.uk/survey-london/vols312/pt2/pp85-100.

${ }^{53}$ A Beautiful World 8 (October 1899): 12; 9 (May 1903): 19-21.

${ }^{54}$ Burgh Police (Scotland) Act, 1903, 3 Edw. 7, c. 33, s. 76.

${ }^{55}$ Public Health Acts Amendment Act, 1907, 7 Edw. 7, c. 53, s. 91.

${ }^{56}$ The Times, 22 September 1910, 6.

${ }^{57}$ Lord Newton, Speech to the House of Lords, 8 May 1923, Parliamentary Debates, Lords, $5^{\text {th }}$ ser., vol. 54 (1923), col. 12.

${ }^{58}$ A Bill Intituled An Act to Amend the Law with Respect to the Regulation of Advertisements, Parliamentary Papers, 1923, I.37; Lord Newton, Speech to the House of Lords, 18 March 1924, Parliamentary Debates, Lords, $5^{\text {th }}$ ser., vol. 56 (1924), col. 807. 
could easily be mistaken for lighthouses or aerodrome lights. The Ministry had opposed a ban in 1923, but now wrote to Guinness, who had been on the verge of purchasing the British patent rights to the invention for $£ 50,000$, requesting that they discontinue sky advertising. Guinness walked away from the deal, and an irate Savage demanded compensation from the Ministry for the "staggering blow" it had dealt him. ${ }^{59}$

Worse was to follow. In January 1932 an article by The Times's aeronautical correspondent talking up the Savage projector and its commercial potential badly backfired: The Times was deluged with letters from outraged members of the public, led by imperial campaigner Lionel Curtis, disgusted at the prospect of the night sky being plastered with advertising messages ${ }^{60}$ Motions condemning the invention were passed by the Council for the Preservation of Rural England (CPRE), the London Society, SCAPA, the Metropolitan Public Gardens Association, and the Commons, Open Spaces, and Footpaths Preservation Society, while the National Trust and the Cambridge Preservation Society also called for controls. ${ }^{61}$ The panic reached to the very top of society, with the King instructing his private secretary to write to the Home Office demanding action. ${ }^{62}$ The outcry led to the appointment of a select committee to investigate the problem and determine the form legislation should

\footnotetext{
${ }^{59}$ Aerial Advertising: Sky-Writing, The National Archives (hereafter TNA), HO 45/19714, Lord Trenchard to Sir John Salmond, 10 March 1931; J. S. Ross to Messrs Arthur Guinness, Son and Co., 29 June 1931; D. H. Hacking to Sir Philip Sassoon, 30 June 1933; Major J. C. Savage to The Secretary, Air Ministry, 17 November 1931; S. Dannreuther to Major J. C. Savage, 22 December 1931. Savage later went public with the episode in a letter to The Times on 12 January $1932,8$.

${ }^{60}$ The Times, 1 Jan. 1932, 7. The subsequent correspondence ran from 6 January to 3 February 1932.

${ }^{61}$ Sky Sign Advertising (Government Policy), TNA, AIR 2/636, "Notes of a Deputation to the Home Secretary from the Amenities Group of the House of Commons, regarding Sky-Writing,” 22 February 1932.

62 TNA, HO 45/19714, A. H. L. Hardinge to H. R. Boyd, 15 January 1932.
} 
take, though the committee in fact preferred self-regulation, recommending that the Home Secretary convene a voluntary body to oversee skywriting. ${ }^{63}$

Neither of Savage's methods of sky advertising flourished, but the controversy they generated persisted, transferring to other, more common forms of aerial advertising later in the decade. Banner-towing aircraft had to fly low for their messages to be read, and the resulting din could cause PR disasters. In November 1937 a plane chartered by Batchelors Peas repeatedly flew over Manchester on Armistice Day, disrupting the two minute's silence and antagonizing local residents. ${ }^{64}$ The Air Ministry, the LCC, and the Metropolitan Police all received complaints from the public about noise from advertising airplanes, and though the number of such complaints was never great, the issue was taken seriously. ${ }^{65}$ Questions were asked in parliament, ${ }^{66}$ while in July 1938 A. P. Herbert, an independent MP, presented a bill to ban what he called this "selfish and unseemly invasion of the heavens." 67 Though the bill failed, sky advertising was considered by a committee later that year as part of a wider investigation into air regulations. While only fifteen aircraft were engaged in banner-towing nationally, the committee believed "that there is a genuine and well-founded feeling on the part of the general public that these aircraft add an unnecessary quota to the burden of

\footnotetext{
${ }^{63}$ Report of the Select Committee on Sky-Writing, Parliamentary Papers, 1931-32, V.623, xvi-xviii.

${ }^{64}$ Manchester Guardian, 12 November 1937, 13; 13 November 1937, 9.

${ }^{65}$ Advertisements - Aerial Advertisements and Skywriting, 1930-57, London Metropolitan Archives (hereafter LMA), CL/GP/1/3, “Advertising by Means of Aircraft,” 13 May 1938. For various communications to the Metropolitan Police on the issue, see Low Flying by Aircraft Towing Advertisement Banners over Central London, TNA, MEPO 2/4682.

6615 May 1935, Parliamentary Debates, Commons, $5^{\text {th }}$ ser., vol. 301, cols. 1698-9; 30 June 1937 , Commons, $5^{\text {th }}$ ser., vol. 325 , cols. $1948-9 ; 8$ July 1937, Commons, $5^{\text {th }}$ ser., vol. 326, cols. 537-9; 8 December 1937 , Commons, $5^{\text {th }}$ ser., vol. 330 , cols. $482,493-4 ; 20$ July 1938 , Commons, $5^{\text {th }}$ ser., vol. 338 , cols. 2191-3.

${ }^{67}$ A. P. Herbert to The Times, 21 June 1938, 17; The Times, 30 July 1938, 8.
} 
nuisances that have to be endured." If the activity ever did become widespread, there would be no hesitation in ordering a ban, so it seemed wisest to terminate the industry now before further capital was invested in it. The committee therefore recommended that no additional planes be purchased by existing firms, and that all banner-towing should cease from October 1941. ${ }^{68}$ SCAPA was delighted: after more than fifteen years of agitation against various forms of skywriting, it had finally got its way. ${ }^{69}$ In fact, war brought sky advertising to an even more abrupt halt, with all civil flying prohibited except by special permit from September $1939 .^{70}$

Yet if the war hastened sky advertising's demise in 1939, it ironically extended its life after 1945. Though the government had not forgotten about sky advertising - in July 1944 an inter-departmental committee on civil aviation in the postwar world recommended "that all forms of aerial advertising should be prohibited" - disagreement over departmental responsibility for the issue prevented action. ${ }^{71}$ At first, this was not a problem, for the continuation of petrol rationing after 1945 made sky advertising impractical. However, when rationing ceased in May 1950, firms could advertise in the skies once more, and by 1955 there were nine businesses offering aerial advertising services. ${ }^{72}$ What really focused attention on their activities was the arrival of sky-shouting, with distressing encounters with

\footnotetext{
${ }^{68}$ The committee thought smoke-writing "the least objectionable method of aerial advertising" - partly because it happened so rarely - and did not recommend any restriction: Report of the Committee on Control of Flying, Parliamentary Papers, 1938-39, IX.357, 11-13, 28.

${ }^{69}$ The Times, 8 July 1939, 9.

${ }^{70}$ Flight, 21 September 1939, 255.

${ }^{71}$ TNA, HO 45/19714, Final Report of Inter-Departmental Committee to Consider Home Civil Aviation Policy, 14.

${ }^{72}$ Aerial Advertising: Proposals for Legislation to Prohibit, 1955-61, TNA, BT 245/38, “Aerial Advertising Bill: Explanatory Notes," n. d.
} 
the new medium reported to the press. ${ }^{73}$ The Ministry of Transport and Civil Aviation began receiving complaints about sky advertising from a variety of sources, ${ }^{74}$ and when local authorities were circularized on the subject, they proved to be overwhelmingly in favor of intervention. $^{75}$

When the matter came before the Cabinet in 1955, Ministers supported a ban, which was eventually achieved as part of the government's Civil Aviation (Licensing) Act in $1960 .^{76}$ The prohibition, which took effect from January 1962, was drafted to include skywriting, sky-shouting, advertising banners, gliders, kites, and balloons. ${ }^{77}$ The ban held through the next two decades, with only a minor loosening of the law in 1971 allowing balloons to display sponsors' markings. ${ }^{78}$ Although carrying advertising continued to be illegal, the new code facilitated the proliferation of colorful, attention-grabbing balloons whose commercial purpose was clear, and this began to make the law seem inconsistent. ${ }^{79}$ In

\footnotetext{
${ }^{73}$ See for example Winifred Gordon Fraser to The Times, 16 June 1955, 9.

${ }^{74}$ Town and Country Planning (Control of Advertisements) Regulations 1948 and Amendment Regulations 1949 and 1951: Aerial Advertising, 1945-58, TNA, HLG 71/1719, A. H. M. Irwin to S. G. G. Wilkinson, Ministry of Housing and Local Government, 12 November 1954; TNA, BT 245/38, "Aerial Advertising," Memorandum by L. C. Nash, 26 October 1959.

75 TNA, HLG 71/1719, Howard Roberts, Clerk of the Council, to Ministry of Housing and Local Government, 9 May 1955; BT 245/38, F. G. Downing to S. R. Walton, 7 June 1955; Dacey to S. R. Walton, Ministry of Transport and Civil Aviation, 31 October 1955.

76 TNA, CAB/128/29/34, Cabinet Minutes, 4 October 1955; CAB/195/14/11, Cabinet Notes, 4 October 1955; TNA, HLG 71/1719, “Aerial Advertising: Instructions to Parliamentary Counsel to Prepare Bill,” n. d; Civil Aviation (Licensing) Act, 1960, 8 \& 9 Eliz. 2, c. 38.

77 The word "aircraft" in the bill legally encompassed balloons and kites: Earl Bathurst, Speech to the House of Lords, 17 May 1960, Parliamentary Debates, Lords, $5^{\text {th }}$ ser., vol. 223 (1960), cols. 912-13.

${ }^{78}$ Flight International, 6 January 1972, 16.

${ }^{79}$ C. Graham South to Flight International, 7 October 1978, 1313; Flight International, 28 March 1981, 927.
} 
the early 1980s, one irate pilot, businessman Brian Bateson, began pressing the question. Having been fined for towing a banner wishing his wife happy birthday in March 1981, Bateson invited further punishment when flying a message reading "Happy Birthday Maggie" along the Blackpool front during the Conservative party conference later that year. Instead, he received a message of thanks from the PM's private secretary. ${ }^{80}$ Indeed, reforming the law suited the wider deregulatory agenda of Margaret Thatcher's government. Iain Sproat, the Under Secretary for Trade now responsible for civil aviation, found the 1962 ban "entirely inappropriate" and thought it put the country in an "embarrassing" position "because in most other countries in the Western World there are no similar restrictions." ${ }^{81}$ In 1982 he promised to present amending regulations to parliament. ${ }^{82}$

Though greeted with a chorus of disapproval from environmentalists which delayed action, after its landslide election victory of June 1983 the government pressed on with the reform. ${ }^{83}$ David Mitchell, the Under Secretary for Transport, with whom responsibility for civil aviation now lay, announced the introduction of new Department of Transport regulations legalizing aerial advertising. This would not trigger a "free for all" thanks to a strict code of practice addressing safety and environmental concerns, in particular the noise issue ${ }^{84}$ The Civil Aviation (Aerial Advertising) Regulations were laid before parliament in

\footnotetext{
${ }^{80}$ Daily Mail, 17 March 1981, 10; Flight International, 14 November 1981, 1466.

${ }^{81}$ Iain Sproat to Ian Gow, 12 April 1983, Margaret Thatcher Foundation: http://fc95d419f4478b3b6e5f3f71d0fe2b653c4f00f32175760e96e7.r87.cf1.rackcdn.com/830412\%20Sproat\%20to\%20Gow\%20AERIAL\%20
} ADS\%20THCR\%202-6-2-173\%20part4\%20f4.pdf

${ }^{82}$ Iain Sproat, Speech to House of Commons, 29 July 1982, Parliamentary Debates, Commons, $6^{\text {th }}$ ser., vol. 28 (1982), col. 620W.

${ }^{83}$ Sproat to Gow, 12 April 1983.

${ }^{84}$ The Times, 11 October 1983, 3; 13 December 1983, Parliamentary Debates, Commons, $6^{\text {th }}$ ser., vol. 50, col. 389W. 
January 1984 and came into effect the following month. Advertising banners, airships and balloons were now legal, while captive balloon advertising was permitted under a separate order which came into operation in May. ${ }^{85}$

\section{TECHNOLOGY AND ADVERTISING}

This troubled hundred-year history tells us much about the British people's relationship with technology, commerce, and modernity. It could be argued that the longevity and intensity of the fears generated by sky advertising corroborate the picture painted by Wiener of a nation uncomfortable with technological progress and seeking refuge in nostalgia and rural fantasy. ${ }^{86}$ Certainly, advocates of skywriting saw opposition as part of an unfortunate national predisposition to antipathy towards technological innovation. According to them, it was a straightforward contest between the forces of progress and reaction. In 1932, Sir Alliott Verdon-Roe, founder of aircraft manufacturers Avro, said that the "hysterical" response to the Savage projector was as ridiculous as the outcry a century earlier against railways when people thought that speeds of 20 miles per hour were dangerous. ${ }^{87}$ But such parallels are misleading. Rieger encourages us to resist seeing "insecurity and disorientation in the face of change" as straightforward evidence for "anti-modern sentiments." Indeed, it is inadequate to think in terms of cultures being pro- or anti-technology. Responses to technology were not uniform; the meanings invested in different technologies varied enormously, which means

\footnotetext{
${ }^{85}$ The Civil Aviation (Aerial Advertising) Regulations, 1983, No. 1885; The Civil Aviation (Aerial Advertising) (Captive Balloons) Regulations, 1984, No. 474.

${ }^{86}$ Wiener, English Culture.

${ }^{87}$ The Times, 13 January 1932, 13.
} 
that we have to study them individually. ${ }^{88}$ Responses to skywriting technologies were complex and multifaceted and cannot be characterized as simply reactionary.

Not all forms of sky advertising attracted hostility. The least controversial of them was the advertising airship, which is perhaps surprising as these vast apparitions must have been a startling sight. The press reported thousands of Londoners looking up at the Mellin Airship on its maiden voyage in 1902 "in every attitude indicative of astonishment and wonder." 89 Not even the evidence airships provided of the home population's vulnerability to aerial attack - during the Mellin voyage Spencer cheerfully dropped little balls onto the crowds below to illustrate "what an army could do with an airship carrying bombs" - could turn the public against the invention..$^{90}$ Indeed, association with war was not enough to damn a technology: the airplane itself was successfully "absorbed into traditional notions of Englishness" in the interwar period in a "dialogue between ancient and modern." In paintings of aerial warfare, fighter-pilots "were depicted as latter-day knights errant," their planes suspended against skies which echoed Constable's cloud studies. ${ }^{91}$

While Britain's culture was not hostile to technology, the hysteria of which VerdonRoe complained did derive in part from the public's experience of other inventions. New technologies were understood not in isolation but in relation to existing technologies: the properties of one could easily bleed into another, serving to heighten anxieties. So, it was

\footnotetext{
${ }^{88}$ Rieger, Technology and the Culture of Modernity, 16, 5.

${ }^{89}$ The Times, 22 September, 1902, 8.

${ }^{90}$ San Francisco Call, 21 September 1902, 19. This did not change in the interwar years, when Britain was haunted by fear of the bomber: Brett Holman, The Next War in the Air: Britain's Fear of the Bomber, 1908-
} 1941 (Farnham, 2014).

${ }^{91}$ Pyrs Gruffudd, "Reach for the Sky: The Air and English Cultural Nationalism," Landscape Research 16, no. 2 (1991): 19-24, at 20 . 
widely believed that Savage's projector would be capable of thrusting electric signs of the kind which lit up Piccadilly Circus into the night sky. Others thought that the projector would turn the heavens into a giant cinema screen with moving pictures. ${ }^{92}$ In plausible extrapolations from their experience of other technologies, contemporaries believed that any limitations would soon be overcome: "little troubles like size and distance, or even atmosphere, are not likely to hold back modern science for long." 93

Such exaggerations were not unique to sky advertising’s opponents, however: its supporters also overstated its power. Indeed, they could be even more wild and fantastical in their predictions. In 1922, the Daily Mail reveled in the technological breakthrough it had funded, in the process grossly overestimating its military applications: "We can now write orders to armies and navies on the sky ... An aeroplane can disappear in a cloud of its own making, or conceal the ships it is escorting in a dense mist."94 The Times was just as guilty. Ronald Carton, the paper's aeronautical correspondent in the 1920s, imagined the sky as a new, revolutionary medium for communication: "If one machine can write one or two words at an altitude of ten thousand feet, to be read by millions of people simultaneously, there is no reason why sentences should not be produced rapidly by a fleet of machines." By these means, important information could be quickly communicated to the entire country: "A simpler means of broadcasting news it is difficult to imagine." 95

\footnotetext{
92 TNA, AIR 2/636, "Notes of a Deputation"; Margot Asquith to The Times, 21 January 1932, 8; Carmichael Thomas to The Times, 19 January 1932, 8; The Times, 6 January 1932, 11.

${ }^{93}$ The Times, 6 January 1932, 11. See also Lionel Curtis to The Times, 3 February 1932, 8.

${ }^{94}$ Daily Mail, 1 June 1922, 8.

95 The Times, 18 August 1922, 5. Carton was a versatile journalist who did not have a background in aeronautics: The Times, 11 July 1960, 14. For other over-enthusiastic predictions, see Marvin, When Old Technologies Were New, 184-9.
} 
The pace of technological innovation from the late nineteenth century, then, meant that the power of individual technologies was commonly overstated. What made the prospect of aerial advertising so chilling to its opponents was the fusion of these particular technologies with an aggressively expansionist commercial culture. ${ }^{96}$ Advertising had long been a feature of the city, but thanks to the growth of consumer society and developments in printing technology it was becoming an increasingly assertive presence from the $1880 \mathrm{~s} .{ }^{97}$ The commercial colonization of public space by the advertising poster began to spark profound disquiet. Letter-writers complained about "The Horrors of the Walls," while Punch cartoons depicted a public "harried and hassled" by an aggressive advertising culture. ${ }^{98}$ Fiction of the time conveys the sense that advertising wanted to inhabit all space: George Gissing's In the Year of Jubilee (1894), set in 1887, depicts a London in which advertising was inescapable, whether on the tram or at the railway station: King's Cross is a "battle-ground of advertisements"; "High and low, on every available yard of wall, advertisements clamored to the eye ... all the produce and refuse of civilization announced in startling letters, in daubed effigies, base, paltry, grotesque.” Not even rural spots were safe - Gissing's ambitious advertising agent Luckworth Crewe outlines his plans to plaster an underdeveloped seaside resort with advertising - along the pier, on the bathing machines, and on the pleasure boats,

\footnotetext{
${ }^{96}$ All of the forms of sky advertising discussed in this article were also occasionally used by politicians, but it was the commercial uses which were more prevalent and attracted the most attention. One of the earliest examples of sky advertising for political ends was a captive balloon displaying the slogan "Vote for Vicary Gibbs" during the 1892 election: Funny Folks, 23 July 1892, 234.

97 John Hewitt, "Poster Nasties: Censorship and the Victorian Theatre Poster," in Visual Delights: Essays on the Popular and Projected Image in the $19^{\text {th }}$ Century, ed. Simon Popple and Vanessa Toulmin (Trowbridge, 2000), 154-69, at 157; T. R. Nevett, Advertising in Britain: A History (London, 1982), 86-92.

${ }^{98}$ Hewitt, "Poster Nasties," 154-6; David Welsh, Underground Writing: The London Tube from George Gissing to Virginia Woolf (Liverpool, 2010), 61-5.
} 
while the caves will be lit with electricity, and "painted all round with advertisements of the most artistic kind." 99

Paralleling the real extension of advertising in the late nineteenth century was advertisers' imaginative colonization of space, performed in their own advertising. Pears' Soap were leaders in this, their advertisements imagining their slogans appearing in places as diverse as the Sudan and the White Cliffs of Dover, while an advertisement for Clarke's Lights displayed their name on Egypt's pyramids. ${ }^{100}$ The recurring presence of Africa in these advertisements underlines that this was an exercise in commercial colonization: "an Empire of things," as Richards puts it. ${ }^{101}$ And advertisers also enjoyed imagining their brands in the sky. Brooke's Soap depicted their famous Monkey Brand character sitting comfortably on the crescent moon, while Pears showed a witch on a broomstick compelled "To Write the Name of Pears on the Sky ... Because it is written all over the Earth." 102 The ambition of advertisers was noticed and satirized by Punch: a cartoon depicts an upstart manufacturer, $\mathrm{Mr}$ Blokey, and his wife admiring a serene moonlit sky. Mrs Blokey remarks on the beauty of the scene, but her husband replies, “Ah! And wouldn't it do one's 'art good to see 'BLOKEY AND SON'S PICKLES' printed right across it in capital letters, big enough for all the world to read with the naked hi!"103 The idea of advertising in the sky also became a staple of late Victorian science fiction, which speculated that in the future the moon would be used as "a

\footnotetext{
${ }^{99}$ George Gissing, In the Year of Jubilee (London, 1947 [1894]), 309, 424.

${ }^{100}$ Illustrated London News, 27 August 1887, 249; 29 October 1887, 524; 10 August 1895, 189. Thirteen years after Pears' advertisement, US firm Quaker Oats actually did place an advertisement on Dover's cliffs, to widespread disgust: Paul Readman, "Preserving the English Landscape, c. 1870-1914," Cultural and Social History 5, no. 2 (2008): 197-218, at 205-6.

${ }^{101}$ Richards, Commodity Culture, 165.

102 Illustrated London News, 22 November 1890, 665; Punch, 11 May 1895.

${ }^{103}$ Punch's Almanack for 1886, 1 January 1886, 18
} 
big sign board that all nations see and read at will," or imagined the sky itself as a billboard. ${ }^{104}$ "Celestial Advertising," a short story by French author Villiers de L'Isle-Adam, detailed the plan of a visionary businessman "to make the firmament profitable" by projecting advertisements into the night sky. ${ }^{105}$ The latter idea was taken further in the fantasy story "In the Year 2889," by Jules Verne and his son Michel, which describes cloudprojected adverts so enormous that "they may be seen by the populations of whole cities or even entire countries."106

Thus, the sky was imagined as the final frontier in advertising's inexorable expansion, with technology making businessmen's wildest dreams realizable. This meant that each new skywriting innovation was received in a climate of heightened apprehension. When captive balloons and sky signs first appeared, cartoons depicted the skies blotted out by them, as in this Punch cartoon (figure 2), just as they depicted urban landscapes awash with posters. Advertisers had "filled our streets" and omnibuses with "pictorial designs more or less horrible in character," complained The Spectator, and they had even "burrow[ed] underground," lining tube station walls with their messages, "but let us not be robbed of our sky also." ${ }^{107}$ Later, Savage's projector meant that "the night skies in every part of the world

\footnotetext{
${ }^{104}$ Kenneth Folingsby, Meda: A Tale of the Future (privately published, n. d.), 105-7. The story was written in 1888.

${ }^{105}$ Villiers de l'Isle-Adam, “Celestial Advertising,” in Sardonic Tales, trans. Hamish Miles (New York, 1927), 44.

${ }^{106}$ The story was first published in the American magazine Forum in 1889. See also Skelton Kuppord, A Fortune from the Sky (London, 1903) and George Allan England, "A Message from the Moon. The Story of a Great Coup,” Pearson's Magazine, April 1907. Plot summaries of both can be found in Everett F. Bleiler, Science-Fiction: The Early Years (Ohio, 1990), 223, 416.

${ }^{107}$ The Spectator, 30 August 1890, 12. For similar sentiments, see Birmingham Daily Post, 3 September 1890, 4; Arthur Severn to The Times, 13 October 1890, 7.
} 
will be plastered with advertisements"; his projections would soon "cover practically the entire sky." ${ }^{108}$ Even whimsical responses like this W. K. Haselden cartoon of 1932 (figure 3) reinforced the idea that the sky would soon be crammed full of messages, above towns, above the countryside, and globally - one panel depicts skywriting over the Pyramids. The marriage of technology and consumer culture induced a nightmarish vision of the future. When sky advertising hit its stride, predicted one despairing Liberal peer, the "whole population would be bound like slaves to an advertising machine."109

\section{COMMERCE, THE CITY, AND MODERNITY}

The configuration of urban space was the subject of enduring disagreement between different groups, including, among others, small-scale retailers, department store proprietors, architects, government, and the press. These conflicts were not simply clashes between advocates of rival architectural styles; rather, cities, as Erika Rapport argues, became battlegrounds "between competing visions of English society, economy and culture." ${ }^{110}$ With the late Victorian development of consumer society, how far commercialism should be permitted to shape the urban environment became a question of growing importance. The commercialization of urban space mapped onto wider questions of tradition and modernity in complex ways. So, although hostility among smaller businesses to department stores in late Victorian London looks at first glance like a simple clash between old and new forms of

\footnotetext{
${ }^{108}$ Lionel Curtis to The Times, 6 January 1932, 11; Guy Dawber, Select Committee on Sky-Writing, q. 429, p. 47.

${ }^{109}$ Lord Dickinson, Select Committee on Sky-Writing, q. 623, p. 68.

${ }^{110}$ Erika Rappaport, “Art, Commerce, or Empire? The Rebuilding of Regent Street, 1880-1927,” History Workshop Journal 53, no. 1 (Spring 2002): 94-117, at 95.
} 
retail, Rappaport warns that "to cast these merchants as conservatives repudiating modernity is a simplistic reading of both the local and the national economies." ${ }^{111}$ Debates on aerial advertising were part of this wider discourse on the commercialization of urban space, and here too, we get a misleading picture if we see them as straightforward battles between the forces of modernity and conservatism.

Advertising was not necessarily a signifier of progress and modernity. Although it undoubtedly represented the new commodity culture whose rapid expansion was a feature of the late Victorian years, its frequently cluttered and disorganized appearance epitomized a form of unplanned, laissez-faire capitalism which was beginning to seem old-fashioned in an age of "new liberalism" and emerging socialism. Street advertising in the late Victorian years was abundant, messy, chaotic, a "pandemonium of signification," as Richards calls it. ${ }^{112}$ Clashing posters jostled for attention, having to resort to ever-more shocking effects to be noticed. The overall effect was overwhelming, jarring, tiring. Sky advertising seemed a development of this wild free-for-all, and when critics imagined its future, invariably the chaos and dissonance of the hoardings was transferred to the skies, as seen in figure 2.

If advertising was an ambiguous symbol of modernity, the organizations which criticized it were not motivated by a simple rejection of modernity. Dominated by a progressive alliance of Liberals and socialists from its formation until 1907, the LCC embodied a self-consciously modern, interventionist approach to the problems thrown up by laissez-faire capitalism. ${ }^{113}$ Paul Readman has argued persuasively that preservationist

\footnotetext{
${ }^{111}$ Erika Rappaport, Shopping for Pleasure: Women in the Making of London's West End (Princeton, 2001), 17, see also 176.

${ }^{112}$ Richards, Commodity Culture, 16.

${ }^{113}$ Richard Dennis, Cities in Modernity: Representations and Productions of Metropolitan Space, 1840-1930 (Cambridge, 2008), 30.
} 
organizations like SCAPA, consistent enemies of sky advertising, did not oppose industrial modernity: "Wanting not to renounce modern life, they sought rather to enrich it."114 Similarly, the London Society, though often critical of "commercial incursions into the cityscape," did not simply reject commercialism; rather they were motivated by "a vision of an ordered capitalism, channeled toward the improvement of the city." 115 This vision could accommodate advertising, provided it was ordered, dignified, and in harmony with its surroundings. The ideal was embodied by the London Underground's interwar advertising under the direction of Frank Pick, a fierce critic of skywriting. ${ }^{116}$ The commercial character of advertising was not the problem ("commerce being a thoroughly sound thing," as Lionel Curtis noted), rather the relationship between the advertisement and its setting. When placed in a scene of natural or architectural beauty, "disharmony" was the result, and it was this that opponents disliked. ${ }^{117}$

A wish for ordered, tidy advertising was of far more than simply aesthetic concern. Unruly sky advertising influenced the behavior of pedestrians and road-users below. Advertising balloons often attracted crowds of onlookers: the press noted that "there must be tens of thousands of idlers who amuse themselves daily by watching the vagaries of these

\footnotetext{
${ }^{114}$ Paul Readman, “Landscape Preservation, 'Advertising Disfigurement,' and English National Identity, c. 1890-1914," Rural History 12, no. 1 (April 2001): 61-83, at 76.

${ }^{115}$ David Gilbert, “London of the Future: The Metropolis Reimagined after the Great War," Journal of British Studies 43, no. 1 (January 2004): 91-119, at 92, 114.

${ }^{116}$ Ibid., 113-14; Michael Saler, The Avant-Garde in Interwar England: Medieval Modernism and the London Underground (Oxford, 1999). Pick gave evidence to the 1932 Select Committee.

${ }^{117}$ Lionel Curtis, Select Committee on Sky-Writing, qq. 710-11, p. 81.
} 
floating advertisements." ${ }^{118}$ The blocked thoroughfares this could cause were a nuisance, ${ }^{119}$ but the arrival of smoke-writing in the 1920s threatened even worse, with Commissioner of the Metropolitan Police, Sir William Horwood, convinced that it was only a matter of time before such spectacles caused a fatal accident. The number of road causalities was already high, and he "strongly deprecated" anything that made people look at the sky rather than where they were going. ${ }^{120}$ The low-flying banner-towing planes of the 1930 s were equally problematic: as well as exacerbating traffic congestion they encouraged "Johnny Head-in-Air by giving him something to look up to as he walks along the street." ${ }^{121}$ It was a persistent fear: motoring groups were prominent in lobbying against sky advertising in the $1950 \mathrm{~s} .{ }^{122} \mathrm{~A}$ constant distraction, sky advertising was therefore an obstacle to the free and safe circulation of bodies and vehicles around the modern city. Rather than producing a city of rational citizens going about their daily business, aerial advertising encouraged sky-gazing idlers symbols of a vacuous commercial culture - to clog up the arteries of the city. In this way, the skywriting debates echoed concerns that London's department stores were luring a "vast

${ }^{118}$ Pall Mall Gazette, 10 May 1886, 4-5. See also Manchester Times, 17 October 1885, 7; Judy, 4 November 1885,221

119 They could also be the subject of legal proceedings: The Queen V. Messrs T. H. White and Co., Belfast News-Letter, 17 October 1889, 6.

${ }^{120}$ History of Sky-Advertising over London, 1920-49, TNA, MEPO 2/8458, Sir William Horwood to the Under Secretary of State, Home Office, 28 September 1922; Horwood to The Secretary, Air Ministry, 26 November 1920. For more on road safety see Joe Moran, “Crossing the Road in Britain, 1931-1976,” Historical Journal 49, no. 2 (June 2006): 477-96.

121 “A Tired Member of the Public" to The Times, 8 May 1937, 15; Maurice Healy to The Times, 25 June 1938, 13.

1221 April 1957, Parliamentary Debates, Commons, $5^{\text {th }}$ ser., vol. 568 (1957), cc18-9W. 
army of window gazers" into the West End, irrational shoppers who both "signified and helped produce England's decline."123

Sky advertising compromised the health of cities in other ways. As cities grew larger, the deleterious impact of disconnection from nature caused growing concern. Horizontal expansion put increasing distance between a city's inhabitants and green spaces, prompting campaigns for the construction of parks and boulevards, frequently conceptualized as a city's "lungs." 124 It also increased the significance of the sky to the city-dweller as a point of connection with the natural world. Vertical expansion jeopardized access to light and air, prompting the LCC to secure legislation restricting the height of new buildings, to 90 feet in 1890, and to 80 feet in $1894 .{ }^{125}$ Despite these limits, tall buildings continued to contribute to a growing sense of enclosure in the modern city. In Howards End (1910), E. M. Forster observes that "month by month the roads smelt more strongly of petrol, and were more difficult to cross, and human beings heard each other speak with greater difficult, breathed less of the air, and saw less of the sky."126 These concerns formed an important backdrop to debates on sky advertising; indeed, part of the opposition to sky signs in the early 1890 s derived from fears that they would further deprive city-dwellers of light and air. ${ }^{127}$ Although

\footnotetext{
${ }^{123}$ Rappaport, “Art, Commerce, or Empire?,” 104, 96.

${ }^{124}$ Richard Dennis, Cities in Modernity, 40.

${ }^{125}$ Richard Dennis, “"Babylonian Flats’ in Victorian and Edwardian London,” London Journal 33, no. 3
}

(November 2008): 233-47.

${ }^{126}$ E. M. Forster, Howards End (London, 1992 [1910]), 115.

${ }^{127}$ For discussions of sky signs in the context of the "light and air" debates see The Graphic, 6 September 1890 , 251; Bristol Mercury and Daily Post, 11 December 1890, 5; Reynolds's Newspaper, 4 January 1891, 8. For more on light and air, see David Rooney, "Visualization, Decentralization and Metropolitan Improvement: 'Light-and-Air' and London County Council Photographs, 1899-1908,” Urban History 40, no. 3 (August 2013): 462-82. 
skywriting's supporters tried to stress its compatibility with nature, ${ }^{128}$ opponents presented it as a violation of nature, a form of "pollution." 129 The sky was "almost the only part of the outer world" many poorer Londoners ever glimpsed, said The Scotsman: "Why should their view of the clouds or the stars be interrupted by artificial clouds conveying information for which they have not asked?"130 The Observer agreed: "There are only two aspects of natural beauty left inviolate to the majority of Londoners - the green grass and the blue sky. If the one is to be vulgarised by catchpenny advertisement, what is to exempt the other?"131

The idea was picked up in interwar fiction. In Aldous Huxley's dystopian Brave New World (1932), sky signs form a "separating screen" between nature and city dwellers, whose appreciation of natural wonders has, as a result, died. Huxley writes, "It was a night almost without clouds, moonless and starry; but of this on the whole depressing fact Lenina and Henry were fortunately unaware. The electric sky-signs effectively shut off the outer darkness."132 John Sommerfield's socialist novel May Day (1936) adopts more violent imagery, depicting sky advertising as a brutal assault on nature: "Searchlights, big guns bombarding the sky with rays of absinthe-green and rose-pink, projected the names of automobiles and film stars on to a moving screen of clouds. The whole sky glowed with a dull red heat from the violence of the electric blows that were showered upon it."133

\footnotetext{
${ }^{128}$ Daily Mail, 2 June 1922, 7-8; 13 June 1922, 7.

${ }^{129}$ Lord Newton, Speech to the House of Lords, 8 May 1923, Parliamentary Debates, Lords, $5^{\text {th }}$ ser., vol. 54 (1923), col. 12.

${ }^{130}$ The Scotsman, 17 May 1923, 6.

${ }^{131}$ The Observer, 20 May 1923, 12.

${ }^{132}$ Aldous Huxley, Brave New World (London, 1994 [1932]), 67.

${ }^{133}$ John Sommerfield, May Day (London, 2010 [1936]), 189.
} 
A growing preoccupation with the psychological impact of city life sharpened these fears. From the mid-nineteenth century, cities were increasingly characterized as exhausting and stressful spaces by poets, novelists, scientists, and sociologists. ${ }^{134}$ As Britain urbanized, the sky acquired new value as a safety-valve, a store of beauty and calm to which tired citydwellers could turn for escape from sensory overload and jangled nerves. But when advertising encroached, this route was closed off. The sky signs of the 1890 s were so objectionable because they deprived "the disgusted wayfarer of the very last rest for his wearied eyes." $" 135$ An Oxford Graduate invoked Ruskin in order to convey what was at stake. Walking through London in the 1890s was to be bombarded with "ever-increasing" numbers of advertisements

defacing the buildings they cover, and exhausting the senses of the observer, till at last the jaded eye seeks the sky which, "almost spiritual in its tenderness, almost Divine in its infinity," is still left to us, but which, if some stand is not made against this hateful innovation, will be gradually obscured by the advertising agent, till it becomes nothing more than the background for a heterogeneous assemblage of tradesmen's notices. ${ }^{136}$

The psychological cost of sky advertising was an enduring concern. Forty years later, members of the public continued to value the sky as a refuge: one woman wrote that when a student in London it was my misfortune ... to wait each evening for an omnibus at the corner of Tottenham Court-road and Oxford-street. While waiting there I habitually sought refuge from the shattering noises of the street, the dazzle of electrically announced

\footnotetext{
${ }^{134}$ Mark Jackson, The Age of Stress: Science and the Search for Stability (Oxford, 2013).

${ }^{135}$ The Graphic, 6 September 1890, 251.

${ }^{136}$ Oxford Graduate to The Times, 3 September 1890, 6. See also Glasgow Herald, 8 September 1890, 6.
} 
cough cures, and the coughs of my fellows, in the untouched stillness of the night sky. Have the advocates of sky advertising any right to take from me and my kind a most necessary haven in this age of tumult? ${ }^{137}$

As this reference to "the shattering noises of the street" suggests, modern urban life was increasingly recognized as not only visually, but also aurally, exhausting, and campaigns against noise were an important manifestation of wider anxieties about urbanization and mechanization. ${ }^{138}$ Noise was becoming a political and medical issue in the 1930 s with the formation in 1934 of the Anti-Noise League, later renamed the Noise Abatement Society (NAS). The battle against noise, claimed the NAS's figurehead, Lord Horder, was as important as the fight against infectious diseases: while noise was not deadly, it did "wear down the nervous system" and acted to "stultify the spirit ... the element in us which marks us off from the beasts." ${ }^{139}$ So when low-flying banner-towing aircraft first began appearing in numbers in the mid-1930s, it was in a climate which was quick to problematize the noise they made. Unfortunately for the advertisers, banner-towing arrived against the backdrop of a rapidly expanding RAF, the gradual growth of commercial passenger services, and more pleasure flying by hobbyists, ${ }^{140}$ all of which exposed the population to unprecedented levels of stress from the air. The NAS lobbied the Air Ministry for a blanket ban on air

\footnotetext{
${ }^{137}$ Mary C. Webb to The Times, 25 January 1932, 8.

${ }^{138}$ James G. Mansell, "Neurasthenia, Civilization, and the Sounds of Modern Life: Narratives of Nervous Illness in the Interwar Campaign against Noise," in Sounds of Modern History: Auditory Cultures of $19^{\text {th }}$ - and $20^{\text {th }}$ Century Europe, ed. Daniel Morat (New York, 2014), 278-303, at 287.

${ }^{139}$ Cited in Jon Agar, "Bodies, Machines and Noise,” in Bodies/Machines, ed. Iwan Rhys Morus (Oxford, 2002), 197-220, at 203.

${ }^{140}$ Gordon Pirie, "Incidental Tourism: British Imperial Air Travel in the 1930s,” Journal of Tourism History 1, no. 1 (March 2009): 49-66 at 50-2.
} 
advertising. ${ }^{141}$ But demand also came from members of the public, who had internalized the NAS's language of shattered nerves, with one Sydenham resident writing to the LCC asking councilors to put a stop to the noise "which is making so many nervous wrecks" in London. ${ }^{142}$ Writers to the press complained that the "relentless, grinding noise" of advertising airplanes disrupted work and leisure: children were kept from their sleep, patients' rest was undermined, doctors were distracted, and seaside calm was shattered by what The Times dubbed "uncivil aviation." ${ }^{143}$ And of course, with the arrival of sky shouting in the 1950s, the association of sky advertising with noise became even closer.

Sound and vision came together to create a uniquely disruptive experience, as is conveyed in the description of a skywriting airplane in Virginia Woolf's Mrs Dalloway (1925). When the plane suddenly appears, the sound "bored ominously into the ears of the crowd ... into the ears of all people in the Mall, in the Green Park, in Piccadilly, in Regent Street, in Regent's Park." Everyone stops what they are doing to stare into the sky. One woman reads the name of the product being advertised aloud "in a strained, awe-stricken voice ... her baby, lying stiff and white in her arms, gazed straight up." Another murmurs the name "like a sleepwalker."144 Instead of the sky as sanctuary, a means of solitary, peaceful communion with nature, here sky advertising causes an imposed and disruptive collective experience. As such, it can be seen as an example of the compression of time and space

\footnotetext{
${ }^{141}$ The Times, 15 December 1937, 18; C. H. Robinson to The Times, 18 April 1938, 6.

${ }^{142}$ LMA, CL/GP/1/3, L. Finch to LCC, 30 April 1938; see also Claude Garnett to LCC, 15 May 1938.

${ }^{143}$ Anthony Crossley to The Times, 18 May 1935, 10; Mrs Ponsonby to The Times, 24 May 1935, 12; "Thistle" to The Times, 15 May 1937, 13; A. P. Herbert to The Times, 21 June 1938, 17; Dr Geoffrey Bourne to The Times, 25 June 1938, 8; C. Weller Kent to The Times, 2 July 1938, 8.

${ }^{144}$ Virginia Woolf, Mrs Dalloway (Alma Classics, 2012 [1925]), 18-19.
} 
widely believed to be a key characteristic of modernity. ${ }^{145}$ The way that Woolf uses the plane to move from character to character, and across several parts of central London, underlines the point that sky advertising could reach unprecedented numbers of people over wide spaces almost simultaneously.

The compulsion involved meant that sky advertising undermined the principle of freedom of choice on which the consumer society rested. If an advertisement in a newspaper or magazine offended, the reader could simply turn the page and forget about it. To some degree, this was also true of objectionable hoardings, despite their size: walk on, and the nuisance was gone. But advertising across the skies monopolized the attention: it removed the consumer's freedom to choose whether or not to look. ${ }^{146}$ When Savage's projector threatened to fill the night skies with messages, the argument became stronger still. Former Lord Justice General Viscount Dunedin was able to tolerate "the detestable sight of the blazing advertisements" in Trafalgar Square because, not living in the area, he soon walked past them and his sense of disgust faded. "But if at all times when I looked at the sky I saw something of the same sort my feelings would be different."147

The argument became irresistible when sky advertising began to force itself on the public's ears as well as their eyes, making it even less possible to ignore the commercial message. Even before it had been experienced in Britain, the 1932 select committee placed sky-shouting beyond the pale on the grounds that a "raucous noise is forced upon the hearing

\footnotetext{
${ }^{145}$ David Harvey, The Condition of Postmodernity: An Enquiry into the Origins of Cultural Change (Cambridge, Massachusetts, 1990), ch. 16. See also Peter Sloterdijk, In the World Interior of Capital (Cambridge, 2014), 251.

${ }^{146}$ E. Boyer-Brown to The Times, 29 August 1890, 10.

${ }^{147}$ The Times, 15 January 1932, 13.
} 
of men and women whether they wish it or no." ${ }^{148}$ When the practice did appear, complaints centered on the "intrusion of ... privacy" it entailed, a criticism which could not be made of

most other forms of advertising. ${ }^{149}$ Even Flight magazine, a supporter of most forms of aerial advertising, thought sky-shouting "an intolerable intrusion upon personal freedom and privacy" for this reason. ${ }^{150}$ The sensory assault involved in sky advertising made it uniquely vulnerable in political terms, and meant that opposing it could easily be squared both with free market ideology, and with support for other forms of advertising. In this way could the ideology of freedom of choice protect public spaces from commercial intrusion.

\section{MODERN SKIES}

The skywriting debates highlight the contested meanings of the sky in the modern age. Savage was adamant that science and technology had opened the sky up for business in the twentieth century. Throughout human history, the sky had been "the vault of heaven," unexplored by man and therefore feared and revered in equal measure. But in the airplane age, the sky had "lost most of its mysteries" and had become just another "highway," carrying passengers and mail. Younger people accepted this unquestioningly: it was only older minds which clung stubbornly to the idea of the sky as sacrosanct. ${ }^{151}$

In fact, this process did not being with the airplane. Earlier advances in astronomy and meteorology may have contributed to a secularization of the heavens, part of a broader

\footnotetext{
${ }^{148}$ Select Committee on Sky-Writing, vi.

149 The quote is from a petition signed by 17 Richmond householders to their local council: The Times, 18 June 1955,4

${ }^{150}$ Flight, 1 July 1955, 1.

${ }^{151}$ Select Committee on Sky-Writing, q. 2, pp. 2-3.
} 
process of reconfiguring attitudes to nature. Kevin Robins and Frank Webster describe this as "a bare, secularised, abstract conception" of the natural world, which "came to be seen as a force, not just to be observed and classified, but dominated, capitalised and transformed."152 Changing attitudes to the sky can be traced back to the early Victorian period. The crisis of faith experienced by many Victorians was sometimes expressed in terms of a changed relationship with the sky. Clergyman Frederick Robertson described the awful moment when the soul begins to find that the props on which it has blindly rested so long are, many of them, rotten, and begins to suspect them all ... the grave appears to be the end of all, human goodness nothing but a name, and the sky above this universe a dead expanse, black with the void from which God himself has disappeared. ${ }^{153}$

J. A. Froude felt a similar sense of loss, wishing "for one week of my old child's faith ... Oh, for one look of the blue sky, as it looked then when we called it Heaven!"154

However, these changes should not blind us to significant continuities. Scientific discoveries notwithstanding, natural phenomena in the skies continued to be read as divine portents in the modern age. "Sky battles" - sustained military encounters featuring horses, pikemen, and cannon-fire - were a common sight in Hanoverian Britain, while meteor showers retained their ability to frighten the superstitious well into the nineteenth century. ${ }^{155}$

\footnotetext{
152 Robins and Webster, Times of the Technoculture, 29-30.

${ }^{153}$ Quoted in Walter E. Houghton, The Victorian Frame of Mind, 1830-1870 (New Haven, 1957), 73.

${ }^{154}$ J. A. Froude, The Nemesis of Faith (London, 1849), 28.

155 Vladimir Jankovic, “The Politics of Sky Battles in Early Hanoverian Britain,” Journal of British Studies 41, no. 4 (October 2002): 429-59; Charles P. Knight to The Times, 15 October 1859, 11.
} 
And rather than demystifying the sky, science could actually enhance its spiritual content. ${ }^{156}$ The productions of artists, poets, and writers testify to the new beauties seen in the nineteenth-century sky, from the vivid and naturalistic skyscapes of Constable and Turner, ${ }^{157}$ to the novels of keen amateur astronomer Thomas Hardy, for whom the night sky was "a work of art superlatively beautiful," providing consolation through its utter disconnection from "the sights and sounds of man." ${ }^{158}$ No one valued the sky more highly than Ruskin, whose appreciation was informed by over fifty years of meteorological observations. ${ }^{159}$

The language used in debates highlights just how deeply the prospect of commercial messages in the sky offended spiritual sensibilities. ${ }^{160}$ By the 1930 s - when Savage believed that the demystification of the sky was at an advanced stage - references to the "desecration" of the "heavens" were in fact becoming more frequent. ${ }^{161}$ For Lewis Farnell, skywriting was

\footnotetext{
${ }^{156}$ Anna Henchman, The Starry Sky Within: Astronomy and the Reach of the Mind in Victorian Literature (Oxford, 2014); Katharine Anderson, "Looking at the Sky: The Visual Context of Victorian Meteorology,"
} British Journal for the History of Science 36, no. 3 (September 2003): 301-32; Vladimir Jankovic, Reading the Skies: A Cultural History of the English Weather, 1650-1820 (Chicago, 2001); Richard Hamblyn, The Invention of Clouds: How an Amateur Meteorologist Forged the Language of the Skies (London, 2002).

${ }^{157}$ John E. Thornes, John Constable's Skies: A Fusion of Art and Science (Birmingham, 1999); John E. Thornes, "Cultural Climatology and the Representation of Sky, Atmosphere, Weather and Climate in Selected Art Works of Constable, Monet and Eliasson," Geoforum 39, no. 2 (March 2008): 570-80; Anderson, "Looking at the Sky."

158 Thomas Hardy, Far from the Madding Crowd (1874), quoted in Anne Dewitt, Moral Authority, Men of Science, and the Victorian Novel (Cambridge, 2013), 101.

${ }^{159}$ Michael Wheeler, "Introduction," in Ruskin and Environment: The Storm-Cloud of the Nineteenth Century, ed. Michael Wheeler (Manchester, 1995), 1-9, at 3.

${ }^{160}$ See for example J. C. to The Times, 29 August 1890, 10; J. M. S. Brooke to The Times, 4 September 1890, 5; Birmingham Daily Post, 13 May 1893, 6.

${ }^{161}$ The Times, 9 July 1930, 13; Leslie Scott to The Times, 16 January 1932, 6. 
an "outrage on our spiritual environment"; the architect Sir Herbert Baker bemoaned the "sacrilege" of advertising on the "canopy of heaven above."162 Science had not secularized the skies - as The Times commented, "The most revolutionary theories of modern physics cannot affect man's reverence for the stars." 163 The sky could not be easily untethered from its religious connotations: a 1927 novel by T. F. Powys features an early form of skywriting when a wine salesman projects his slogan "Mr Weston's Good Wine" into the night skies over a village. But all is not as it seems: Weston is in fact God, on earth to sell the light wine of love to the good villagers and the strong wine of death to the sinners. ${ }^{164}$ His skywriting, rather than a commercial affront, thus represents an entirely appropriate reclamation of the skies for divine purposes.

But again, this was not a simple battle between conservatives and progressives. In fact, the panic engendered by skywriting was the result of new ways of conceptualizing air and space, which have been traced by Steven Connor. From the late nineteenth century, Connor argues, "the traditional, poetic conception of the air as a kind of vacancy, the privileged bearer of the idea of the open itself, had to contend with a sense of the crowding of the air, which became liable to congestion, contamination and exhaustion." ${ }^{165}$ Before this, air was fundamentally different from earth or sea: whereas these occupied space, air had "habitually been thought of as space itself, the space within which the other elements are disposed," and therefore was imagined as inexhaustible, infinite, and unknowable. As such, it had limitless powers "to consume and dissolve," which made atmospheric pollution a subject

\footnotetext{
162 The Times, 8 January 1932, 11; 13 January 1932, 13.

${ }^{163}$ Ibid., 6 January 1932, 11.

${ }^{164}$ T. F. Powys, Mr Weston's Good Wine (London, 1960 [1927]).

${ }^{165}$ Steven Connor, The Matter of Air: Science and the Art of the Ethereal (London, 2010), 37-8.
} 
of little concern. ${ }^{166}$ But as the air became "inundated with our traffic, our signals, our detritus," 167 the result was, Connor claims, a "finitizing of the air" or

the loss of belief in the air as the abode of the endless. ... Rather than extending beyond sight, knowledge and belief, merging into the celestial ether of the upper air, the air has come to be seen as no more than a thin and increasingly patchy rind of breathable gas clinging wispily to the surface of the planet. ${ }^{168}$

So Savage was right to think that attitudes to the sky were changing, only he got the trajectory wrong - far from becoming just another highway, the sky was taking on a new significance as a precious, fragile, finite resource which needed to be preserved. In this sense, it was the preservationists who were the moderns, not skywriters like Savage who were influenced by a traditional sense of the air as inexhaustible, and therefore exploitable, space.

In debates on aerial advertising, the sky featured not as empty space waiting to be colonized but as what Lane calls "storied place," a site recognized as sacred because of the "gathered meanings" associated with it. What is important here is not so much the actual reality of place, but the power of the imagination to create significance through perception: landscape, as Lane notes, is "a constructed reality". ${ }^{169}$ So, in a nation struggling to come to terms with the impact of industrialization and urbanization, the sky took on new significance as a reminder of the spiritual, and a cherished national asset, to be protected at all costs. Preservationist movements are sometimes characterized as culturally marginal and self-

\footnotetext{
166 Ibid., 272-4.

${ }^{167}$ Ibid.,281.

${ }^{168}$ Ibid.,275.

${ }^{169}$ Lane, Landscapes of the Sacred, 15, 59, 37.
} 
consciously elitist, ${ }^{170}$ but Readman has stressed their democratic ethos, pointing out that they were inspired by a passionate sense of "collective ownership" of the countryside. Rural advertising was so resented because it asserted private rights over what were held to be "common possessions." 171 This sense of public rights also extended to the sky and, if anything, was felt even more keenly in this domain. Advertising's invasion of the skies mirrored the controversial enclosure of common lands in the seventeenth and eighteenth centuries. Whether the two situations were legally analogous was another matter: who owned the sky, and whether property rights in it were enforceable, was a complex legal question which exercised lawyers over many generations. ${ }^{172}$ But opponents of advertising were adamant that the sight of the sky was a public good which must not be privatized.

Such arguments were evident during the debates on sky signs in the 1890s and became even more pronounced in subsequent controversies. Sky signs threatened "views that are national property." Everyone was entitled to "a full view of the heavens ... the free exercise of the senses with which we are endowed" was "a common birthright" with which no private body should interfere. ${ }^{173}$ In the 1930 s, Savage's projector was seen as an attempt to privatize the view of the sky: G. M. Trevelyan was adamant that "the view of the night sky ought not to be [Savage's] private property."174 The new technology would deprive the public of "The august and inspiring spectacle of the starry night, free to the poorest human being

\footnotetext{
${ }^{170}$ Peter Mandler, “Against 'Englishness': English Culture and the Limits to Rural Nostalgia, 1850-1940,” Transactions of the Royal Historical Society 6th ser., 7 (1997): 155-75.

${ }^{171}$ Readman, "Landscape Preservation," 66.

${ }^{172}$ Stuart Banner, Who Owns the Sky? The Struggle to Control Airspace from the Wright Brothers on (Cambridge, MA, 2008). Banner only briefly touches on aerial advertising: 26.

${ }^{173}$ J. B. Hilditch to The Times, 6 September 1890, 4; 27 August 1890, 7. See also The Times, 3 September 1890, 7.

${ }^{174}$ The Times, 13 January 1932, 13.
} 
who enjoys the gift of sight." 175 Indeed, the opposition's view of skywriting was inherently democratic in that it derived from the point of view of the ordinary pedestrian, not the passenger in the cab or the gentleman in his club, who might not be expected to see or care about advertising in the sky.

To privatize the sky would be as repugnant as advertising on the dome of St. Paul's Cathedral - an analogy which was repeatedly made in order to underline the sky's status as a form of national property. A satire of 1886 imagined a bill passing parliament "to Secure to Mr. Augustus Harris's Balloon an Advantageous Position” on the dome. ${ }^{176}$ The sky sign controversy erupted four years later because one such sign spoiled the view of St Paul's, a point seized upon in figure 2, which depicts the dome dwarfed by the freakish assemblage of sky advertisements which surround it. ${ }^{177}$ This sensitivity did nothing to diminish the allure of St Paul's to the sky advertisers: rounding the dome was the ultimate aim of the early twentieth-century airship pioneers, while many of the earliest smoke-writing stunts were conducted above St Paul's, with C. C. Wakefield and Co. issuing a postcard of the dome with "Castrol" written proudly above it. Other icons of Britishness, such as Nelson's Column, the Cenotaph, and Westminster Abbey, also featured in debates: all of them, noted one commentator ironically, "would make admirable hoardings."

The evocative language used to describe the sky in these debates confirmed it as a national treasure to rank alongside these monuments. Citing Shakespeare, Lionel Curtis complained that Savage's invention would "cover 'this most excellent canopy, the air, look

\footnotetext{
${ }^{175}$ Edward Jenks to The Times, 12 January 1932, 8.

${ }^{176}$ Funny Folks, 22 May 1886, 161.

${ }^{177}$ For a similar image, see Aberdeen Weekly Journal, 17 September 1890, 5.

${ }^{178}$ Miss Agnes Mure Mackenzie to The Times, 14 January 1932, 13; W. Foxley Norris to The Times, 15 January 1932, 13; The Times, 3 February 1932, 13.
} 
you, this brave overhanging firmament, this majestical roof fretted with golden fire' with advertisements projected by searchlights of 3,000,000,000 candle-power." ${ }^{179}$ As well as the Bard, defenders of the sky variously invoked Wordsworth, Shelley, and the Psalms to embed their cause in English cultural heritage. ${ }^{180}$ As late as the 1980s, when the Thatcher government proposed to legalize sky advertising, a critic cited Coleridge's poem "Frost at Midnight" to legitimize his case. ${ }^{181}$ If some of these responses seem excessive, it is because the sky, far from being empty space, overflowed with emotional resonances. The stakes in these debates could hardly have been higher for the opponents of skywriting: the soul of the nation was in the balance. It should come as no surprise, therefore, that in 1932 Curtis noted earnestly to his friend, US businessman Whitney Shephardson, that "to any man with a real sense of proportion," the problem of skywriting was "more important even than the gold standard." 182

\section{OUTCOMES}

Sky advertising controversies had wider-ranging effects. The agitation against sky signs in the early 1890s laid the foundations for a broader campaign to regulate advertising. One of the original critics of sky signs had proposed "the formation of a new organization for the preservation of the picturesque, the suppression of sky signs and objectionable street

\footnotetext{
${ }^{179}$ The Times, 6 January 1932, 11.

${ }^{180}$ Sir Herbert Baker to The Times, 13 January 1932, 13; Sir George Clausen to The Times, 13 January 1932, 13;

W. Foxley Dean to The Times, 15 January 1932, 13.

${ }^{181}$ David Holbrook to The Times, 3 August 1982, 9.

${ }^{182}$ Cited in Deborah Lavin, From Empire to International Commonwealth: A Biography of Lionel Curtis (Oxford, 1995), 264.
} 
advertisements." 183 Indeed, seeing what the LCC could achieve inspired the formation of SCAPA: as its house publication later noted, "The Society took organic form in 1893, in connection with the efforts made to arrest in its beginning the practice of using Sky Signs."184 SCAPA's key purpose was to campaign for legislation to defend town and country from the depredations of advertising, and one of the group's main movers later recognized the LCC's statute as the first to give "any protection against offences of the kind." 185 Thus, it could be said that the battle against advertising began in the skies before it was taken to the land.

The campaigns of SCAPA and other preservationist groups generally received positive press coverage: indeed, The Times was instrumental in whipping up the 1932 skywriting panic. Keen to secure as much advertising revenue to itself as possible, the press was always happy to join campaigns against rival advertising media, for example, siding with the $\mathrm{BBC}$ against proposals for commercial radio and television. ${ }^{186}$ This favorable coverage made it possible to secure legislation regulating or banning sky advertising. Whether the press reflected wider public opinion is of course difficult to gauge. Savage and his supporters claimed that the "man in the street" actually enjoyed skywriting. ${ }^{187}$ But a less enthusiastic response can be inferred from the cautious way in which advertisers approached it. Many large firms were only hesitantly turning to advertising in the early twentieth century and were wary of antagonizing the public, while the advertising agencies, which craved respectability

\footnotetext{
183 J. B. Hilditch to The Times, 6 September 1890, 4.

${ }^{184}$ A Beautiful World, 9 (May 1903): 7.

${ }^{185}$ Lord Balfour of Burleigh, Speech to House of Lords, 24 June 1920, Parliamentary Debates, Lords, $5^{\text {th }}$ ser., vol. 40 (1920), cols. 786-7.

${ }^{186}$ Paddy Scannell and David Cardiff, A Social History of British Broadcasting: Volume One 1922-1939

(Oxford, 1991), 230; Andrew Crisell, An Introductory History of British Broadcasting, $2^{\text {nd }}$ ed. (London, 2002 [1997]), 84-5.

${ }^{187}$ Savage, Select Committee on Sky-Writing, q. 4, p. 5; Thomas V. Church to The Times, 19 January 1932, 8.
} 
and were mindful of the need to appear socially responsible in order to fend off legislative interference in their activities, also wished to avoid controversy. ${ }^{188}$ If skywriting was as popular with the wider public as its supporters claimed, it is likely that advertisers would have embraced it more enthusiastically than they did. As it was, one firm which experimented with Savage's smoke-writing in the mid-1920s abandoned it after it found that the practice prompted as much "irritation" as "admiration" from the public. ${ }^{189}$ The result was, as Savage later admitted, that his innovation was not widely taken up by advertisers - he had to "go out and sell it very hard" - but with little success. ${ }^{190}$ And sky-shouting was not extensively adopted in the 1950s before it was banned partly because of the public's violent antipathy to it. The manager of Aero Publicity, an aerial advertising firm, noted that after it experimented with the new medium, "Police called at the aerodrome, complaints rolled in from all quarters. Local papers gave it space and it was generally considered an intolerable nuisance." As a result, the firm discontinued sky-shouting within a month. ${ }^{191}$

Thus, while the advertising industry was generally proficient at mobilizing to resist legislative interference, it did not seriously contest moves for statutory bans in the 1930s and 1950s. When the high costs were factored in, ${ }^{192}$ it is unsurprising that advertisers saw more potential in conventional media that were far from saturated than what could easily be dismissed as "a mere freak stunt," and a "passing novelty." 193 Little was to be gained by

\footnotetext{
188 This subject is covered at length in Stefan Schwarzkopf, "Respectable Persuaders: The Advertising Industry and British Society, 1900-1939” (PhD diss., Birkbeck College, University of London, 2008).

${ }^{189}$ Alfred H. Angus, Select Committee on Sky-Writing, q. 1491, p. 140.

${ }^{190}$ Select Committee on Sky-Writing, q. 78, p. 14.

${ }^{191}$ S. Pearce-Smith to Flight, 22 July 1955, 142.

${ }^{192}$ Lord Newton claimed that many advertisers supported a skywriting ban because it was "desperately expensive:” 15 May 1923, Parliamentary Debates, Lords, $5^{\text {th }}$ ser., vol. 54 (1923), col. 161.

${ }^{193}$ Alfred H. Angus, Select Committee on Sky-Writing, q. 1491, p. 140; C. R. Vail, q. 1363, p. 128.
} 
investing in new advertising technologies which threatened to damage the reputation of advertising as a whole. Conversely, by renouncing sky advertising, the industry was helping to legitimize the other forms of advertising in which it was engaged. ${ }^{194}$

As a consequence, even if advertising on land remained rampant, it was curbed above the skyline, a fact which became a source of national pride. In 1900, SCAPA's founder Richardson Evans argued that the LCC's sky-sign ban had "saved the metropolis and set an example to the world." 195 The Times agreed, asking "What would London now be ... if there had been no check to the multiplication of sky signs, if every one could advertise in whatever manner and in whatever place he pleased?"196 Though Piccadilly Circus remained associated with brash advertising, this had to take place below the skyline, as can be seen in this photograph of 1910 (figure 4). The restrictions on advertising in the sky had a long-term impact on the capital. In the 1950s, the architect Sir Owen Williams commented that "the total prohibition of sky signs over many years" had "given the distinctive features of the London sky line," preventing "the appearance of London from resembling a Texas oilfield." 197 Other nations did far less to restrict sky signs: in the US "there was a profusion of both business signs and billboards on rooftops nationwide." ${ }^{198}$ France was another leader in

\footnotetext{
${ }^{194}$ Around this time, Shell established itself as an enlightened company by working closely with preservationist groups to remove its "unsightly" enamel signs and boards from the countryside, a policy which proved very lucrative: John Hewitt, "The 'Nature' and 'Art' of Shell Advertising in the Early 1930s," Journal of Design History 5, no. 2 (1992): 121-39.

${ }^{195}$ Richardson Evans to The Times, 18 April 1900, 11.

${ }^{196}$ The Times, 22 March 1900, 9.

${ }^{197}$ Sir Evan Owen Williams to The Times, 17 December 1954, 9; 28 December 1954, 7.

${ }^{198}$ Chicago was an exception, regulating sky signs from 1905, and outlawing rooftop-mounted electric signs in 1911: Martin Treu, Signs, Streets, and Storefronts: A History of Architecture and Graphics along America's Commercial Corridors (Baltimore, 2012), 74.
} 
sky signs, especially electric ones: by the mid-1920s "nearly six thousand neon advertising signs crowded the Parisian night horizon." ${ }^{199}$ From 1925, the Eiffel Tower itself was turned into "a sky-sign at night," being fitted with thousands of electric lamps in order to advertise Citroen, in stark contrast to the purity of St Paul's. ${ }^{200}$

Smoke-writing too developed far more strongly outside the UK. In 1928 the London Correspondent of the Manchester Guardian was relieved to note that the "sky-writing terror" had not flourished in Britain as it had in the US and Germany. ${ }^{201}$ Skywriting quickly became a common sight in interwar America. Lucky Strike was the first to try the new technology, hiring Savage in January 1923 for 350 demonstrations, then ordering a further 1,100, while Pepsi-Cola used skywriting to great effect, significantly raising its profile in the 1930 s. $^{202}$ New York became the home of American skywriting: its "residents received heavenly messages almost daily." ${ }^{203}$ Savage was initially blocked from extending into the skies over Germany by a clause in the Treaty of Versailles, but as soon as this obstacle was overcome in 1926, he signed a deal with Henkel. By the following year, Berlin's skies had been turned into "a hoarding on which advertisements are written in smoke," according to one

\footnotetext{
${ }^{199}$ But restrictions were introduced in 1929: William R. Leach, Land of Desire: Merchants, Power, and the Rise of a New American Culture (London, 1994), 343.

${ }^{200}$ Manchester Guardian, 3 July 1925, 11; The Times, 4 May 1929, 11; 3 July 1972, 13.

${ }^{201}$ Manchester Guardian, 3 May 1928, 10.

202 TNA, AIR 2/636, Major J. C. Savage, “Sky-Writing by Day,” 1; Life, 19 August 1940, 6-8. Pepsi’s rival Coca-Cola was soured on the new technology, however, when deploying it in a Cuban campaign: its message "Tome Coca-Cola" ("Drink Coca-Cola") was blurred by the wind so that it read "Teme Coca-Cola" ("Fear Coca-Cola"): Mark Pendergrast, For God, Country and Coca-Cola: The Definitive History of the World's Most Popular Soft Drink (London, 2000), 169.

${ }^{203}$ Juliann Sivulka, Soap, Sex, and Cigarettes: A Cultural History of American Advertising (London, 1998$), 182$.
} 
contemporary. ${ }^{204}$ Skywriting proved so successful in Germany - Henkel received much praise for its "unique and attractive advertising" - that the firm purchased Savage's patent rights in 1929 for "a very large sum of money," taking over skywriting operations in Germany and neighboring countries. ${ }^{205}$ The more enthusiastic embrace of skywriting elsewhere meant that it became reconceptualized as foreign, a process possibly helped by its frequent appearance in US films and comics. ${ }^{206}$ When the government threatened to legalize sky advertising in the 1980s, many would have only experienced it when travelling abroad: one critic referred to the "sky intrusions" he had been unfortunate enough to witness in Australia and America. ${ }^{207}$ So, the absence of sky advertising could be used as a marker of national difference - despite the fact that many of its forms were British inventions.

\section{CONCLUSION}

That the threat to the sky posed by advertising was often imaginary, or at least greatly exaggerated, does not make it less significant. ${ }^{208}$ The importance of the sky - like the countryside - was as much in the imagination as in reality. ${ }^{209}$ The sky is a "real-and-

\footnotetext{
${ }^{204}$ Manchester Guardian, 14 October 1927, 10.

205 TNA, AIR 2/636, Savage, “Sky-Writing by Day,” 3-4 and appendix 5.

${ }^{206}$ Skywriting scenes occur in Wings in the Dark (1935), The Wizard of Oz (1939), and Reunion in France (1942). The Bat Signal, used to summon Batman and Robin to Gotham City Police headquarters, made its first comic-book appearance in 1942: Mark S. Reinhart, The Batman Filmography, $2^{\text {nd }}$ ed. (Jefferson, 2013), 13. ${ }^{207}$ David Holbrook to The Times, 3 August 1982, 9.

${ }^{208}$ Savage was exasperated that few of his critics had even witnessed his skywriting: Select Committee on SkyWriting, q. 177, p. 21; J. C. Savage to The Times, 23 Jan. 1932, 6.

${ }^{209}$ Burchardt, Paradise Lost, 9, 158.
} 
imagined" space, at once observed and constructed. ${ }^{210}$ A variety of meanings are projected onto it, and studying these, as has been noted in another context, gives us a unique insight into the "deepest fears and anxieties" of past societies. ${ }^{211}$ Developments in science and technology did not automatically divest the sky of its religious significance or its sense of mystery, but they did open up a space in which traditional meanings could be challenged, and new uses for the sky proposed. Yet this was not simply a battle between old and new, for opponents of these new uses were themselves writing new meanings into the skies. For them, the sky was man's most valuable connection to nature in an urban society, a precious but endangered part of the nation's heritage, an essential counterweight to consumer society. It was public not private, and most certainly not-for-profit.

The violation of the sky by the commercial was therefore intolerable. The inevitability of advertising in towns and even parts of the countryside was accepted by all but the diehards: debate focused on how best to control exactly where such advertising appeared, and how to ameliorate its appearance. With aerial advertising it was different: advertising simply did not belong in the sky. Moreover, keeping the skies free from advertising produced the comforting feeling that modern commerce, despite its inherent expansionism, had bounds, that there were parts of life it could not reach. As soon as advertising threatened to break these bounds, anxiety, even panic, usually ensued. The more reputable elements in the advertising industry realized this and responded by focusing their energies in less controversial directions. Thus, the troubled history of sky advertising in Britain is not evidence of the nation's technophobia, or of the self-indulgent aestheticism of the privileged few. It was not about rejecting modernity, but achieving an accommodation with it.

\footnotetext{
${ }^{210}$ For more on "real-and-imagined" space, see Paul Stock, "The Real-and-Imagined Spaces of Philhellenic Travel," European Review of History 20, no. 4 (2013): 523-37, at 527.

${ }^{211}$ Walsham, "Sermons in the Sky," 57-8.
} 
Though sky advertising generated more controversy in Britain than in other nations, it is a subject which still has the ability to fascinate and appall across the world. It remains a staple of fictional dystopias, ${ }^{212}$ and as technology opens up fresh heights to the advertiser, the same debates follow close behind. Outer space, as Campion argues, is imagined in western culture "both as pristine and a source of wisdom"; just like the sky "it is a valued place, rather than a valueless space." ${ }^{213}$ So, it is not surprising that in the space age, the traditional anxieties shifted to this new final frontier. When in 1993 a US company, Space Marketing Inc., announced that it was planning to launch mile-long advertising billboards into space, the proposal was greeted with horror by American environmentalists, astronomers, and politicians; responses, indeed, were very similar to those explored in this article. One Representative complained that the plan "would turn our morning and evening skies, often a source of inspiration and comfort, into the moral equivalent of the side of a bus." For Carl Sagan, it was "an abomination" which meant that "there will be no place on Earth safe from advertisers." This opposition led in 2000 to the passage of a new law banning "obtrusive space advertising," defined as any advertising material visible from earth without the aid of a telescope. ${ }^{214}$ It seems that, at least as far as advertising is concerned, the sky will always be the limit.

\footnotetext{
${ }^{212}$ For a recent example, see Anna Franklin, review of Under Electric Clouds, 11 February 2015: http://www.filmneweurope.com/news/region/item/110213-fne-at-berlinale-2015-competition-under-electricclouds

${ }^{213}$ Nicholas Campion, “The Moral Philosophy of Space Travel: A Historical Review," in Commercial Space Exploration: Ethics, Policy and Governance, ed. Jai Galliott (Farnham, 2015), 9-22, at 11.

${ }^{214}$ Karl Grossman, "Disgrace into Space,” The Ecologist, March 2001, online ed. http://www.space4peace.org/articles/ecologist.htm. For a fuller discussion of the legal ramifications, see Zeldine O’Brien, “Advertising in Space: Sales at the Outer Limits," in Commercial Space Exploration, 91-106.
} 